\title{
Performance Analysis of Regional Civil Service Agency Of The Rembang District
}

\author{
Natalia Kusuma Dewi ${ }^{1}$, Hardi Warsono ${ }^{2}$, Ida Hayu Dwimawanti ${ }^{3}$ \\ Magister of Public Administration Sciences, Faculty of Social and Political Sciences, \\ Diponegoro University $1,2,3$ \\ Email : nataliadewi2412@gmail.com
}

(Received: October 24-2020; revised: November 24-2020; published: December 31-2020)

\begin{abstract}
Performance measurement of a public organization has been an issue in recent years. The State Apparatus has become a pioneer in the success of development to achieve justice and welfare of society. . Negative issues regarding professionalism, especially in the quality and performance aspects of ASN, need to be responded positively by conducting an evaluation. The public generally views that the problem of ASN professionalism can be seen from the lack of integrity, low competence, slow performance, and many disciplinary violations. The Rembang Regency Regional Personnel Agency has carried out a performance appraisal with reference to the Rembang Regency Regional Personnel Agency Performance Agreement in 2019. The assessment provides an overview of the successes and failures in achieving the resulting goals and targets, then categorizing performance (positioning) according to the level of performance achievement. The results of the performance achievement show that the average performance achievement of the Rembang Regency Regional Personnel Agency in 2019 is $90.98 \%$. Coordinate with the Central Government regarding the activities to be implemented so that they can meet the targets for implementing these activities.
\end{abstract}

Keywords: Performance, State Civil Apparatus

\section{INTRODUCTION}

Government apparatus (civil service) has an important role in the management of a country. The State Apparatus has become a pioneer in the success of development to achieve justice and welfare of society. The government apparatus is a bureaucratic "machine" that has the task of providing the widest possible service to the community so that the community becomes prosperous. The empowerment of a group of women craftsmen of weaving in North Central Timor Regency is used as a community small business to support the economic growth of the community in that region. The woven cloth is a cultural heritage that is capable of producing the speed of the regional economy. The handicraft of weaving that is done in TTU district is a very diverse traditional ikat craft.

Realizing the strategic role of the government apparatus, the Government and the House of Representatives have issued Law Number 5 of 2014 concerning State Civil Servants (ASN). ASN is a government apparatus consisting of Civil Servants (PNS) and government employees with a Work Agreement (PPPK). In Law Number 5 of 2014 there is a very radical change compared to the previous Law contained in Law Number 43 of 1999 concerning Amendments to Law Number 8 of 1974 concerning Personnel Principles. Some of these changes include the procurement of 


\section{0 | Jurnal Ilmiah Ilmu Administrasi Publik: Jurnal Pemikiran dan Penelitian Administrasi Publik \\ Volume 10 Number 2, July-December 2020. Page 439-445}

civil servants, career development, compensation and awards, dismissal of civil servants and institutions.

Government organizations, like organizations in general, demand ASN professionalism as the key to success in the process of providing public services (public). Therefore, the professionalism of ASN employees needs to be developed and becomes a special concern for the government. Negative issues regarding professionalism, especially in the quality and performance aspects of ASN, need to be responded positively by conducting an evaluation. The public generally views that the problem of ASN professionalism can be seen from the lack of integrity, low competence, slow performance, and many disciplinary violations.

ASN professionalism index is one way to measure ASN performance. The National Civil Service Agency (BKN) tries to develop a method for measuring the professionalism of employees, which in the end is that the performance of all ASNs will be measured. Measurements are carried out in stages, starting with structural officials. The premise of the ASN professional indicator is that (individual) employees will be more professional if their competence is higher, their performance is getting better and the employees are getting cleaner. Later, the results of this index measurement can map which areas have high indexes and which areas have low indexes. So that the intervention taken can be right.

The ASN Professionalism Index in Rembang Regency is 70.66 and is in the second position from the bottom after Klaten Regency at 67.71. The measurement of ASN professionalism in the Regional Civil Service Agency (BKD) of Rembang Regency is because the calculation of the ASN professionalism index recently only measured structural officials in Rembang Regency, so not all civil servants were measured for their professionalism index.

Performance management is about creating and ensuring effective communication. Management focuses on what organizations, managers and workers need to succeed. Performance management is about how performance is managed to achieve success. Wibowo (2008: 7) According to Costello (Wibowo 2008: 9) states that performance management is the basis and driving force behind all organizational decisions, work effort, and resource allocation.

Employee performance in providing services is a measure of the success of an organization, this is because employees are a factor that can realize effectiveness and efficiency in the implementation of organizational tasks and functions successfully or not, as a whole to meet the needs set by each group with regard to the efforts. systematic and improve the ability of the organization to continuously achieve its needs effectively.

\section{METHOD}

The type of this research is qualitative research with postpovite philosophy that used in natural object conditions and the researcher is the key informant. A generalization so that process and meaning are always highlighted in the qualitative research process (Sugiyono, 2015). The types and sources of data from this study are classified into two categories, namely primary data where the data is data obtained directly and collected through observation and interviews, then secondary data is data obtained from reading sources and other sources can be from personal letters, diaries and official documents from government agencies (Moleong, 2012).

The data collection method used was through interactive interviews with sources related to the performance of ASN in BKD Rembang Regency. The data analysis that the researchers 
Natalia Kusuma Dewi, Hardi Warsono, Ida Hayu Dwimawanti; Performance Analysis of ... $\mid 441$

conducted used an interactive model (Miles, Huberman, and Saldana, 2014) in which data analysis activities consisted of data reduction, data presentation, and drawing conclusions.

\section{RESULT AND DISCUSSION}

Achievement of Regional Civil Service Agency (BKD) Performance In Rembang Regency

The results of work, namely the success of employees in performing work (output) are usually measured by how much has been produced, how many and how much is the increase. Work results are measured in terms of quality and quantity achieved by an employee in carrying out their duties and functions according to the responsibilities assigned to them.

The Rembang Regency Regional Personnel Agency has carried out a performance appraisal with reference to the Rembang Regency Regional Personnel Agency Performance Agreement in 2019. The assessment will provide an overview of the successes and failures in achieving the resulting goals and objectives, then performing performance categorization (positioning) according to the level of performance achievement.

The measurement of the performance targets of the strategic targets that have been set by the Regional Personnel Agency of Rembang Regency is done by comparing the performance targets with the performance realization. Performance indicators as a measure of the success of the strategic goals and objectives of the Regional Personnel Agency of the Rembang Regency and their targets and realization achievements are detailed as follows:

Table 1 :

Achievement of Target Performance in 2019

Goal 1: Improve infrastructure and instruments in support of personnel services and education and training

\begin{tabular}{|c|c|c|c|c|c|}
\hline Goal Indicator & $\begin{array}{c}\text { Target } \\
2019\end{array}$ & $\begin{array}{c}\text { Realization } \\
2019\end{array}$ & $\begin{array}{c}\% \\
\text { Achieveme } \\
\text { nts } 2019\end{array}$ & $\begin{array}{c}\% \\
\text { Achieve } \\
\text { ments } \\
2018\end{array}$ & $\begin{array}{c}\% \\
\text { Achieveme } \\
\text { nts } 2017\end{array}$ \\
\hline 1 & 2 & 3 & 4 & 5 & 6 \\
\hline $\begin{array}{l}\text { Percentage of } \\
\text { employee services }\end{array}$ & $95 \%$ & $100 \%$ & $105,26 \%$ & $100,60 \%$ & $101,96 \%$ \\
\hline $\begin{array}{l}\text { Percentage of } \\
\text { facilities that are fit } \\
\text { for use }\end{array}$ & $80 \%$ & $100 \%$ & $125 \%$ & $100 \%$ & $100 \%$ \\
\hline $\begin{array}{l}\text { Number of employee } \\
\text { service SOPs }\end{array}$ & 10 & 6 & $60 \%$ & $60 \%$ & $60 \%$ \\
\hline \multicolumn{3}{|c|}{ Average Performance } & $96,75 \%$ & $86,87 \%$ & $87,32 \%$ \\
\hline
\end{tabular}

Based on the table above, the achievement of Strategic Targets The increase in infrastructure and instruments in supporting personnel services and education and training was $96.75 \%$, meaning that there was an increase in performance achievements compared to 2017 of $87.32 \%$ and in 2018 which reached the target of $87.32 \%$. Referring to Permendagri Number 54 of 2010 concerning the Stages, Procedures for Compiling, Controlling, and Evaluating the 
442 Jurnal Ilmiah Ilmu Administrasi Publik: Jurnal Pemikiran dan Penelitian Administrasi Publik

Volume 10 Number 2, July-December 2020. Page 439-445

Implementation of the Regional Development Plan, the score of $96.75 \%$ indicates that this strategic target has received a "very good" assessment criteria.

Table 2 :

Achievement of Target Performance in 2019

Goal 2: The realization of career planning and development for civil servants based on qualifications and competencies

\begin{tabular}{|c|c|c|c|c|c|}
\hline Goal Indicator & $\begin{array}{c}\text { Target } \\
2019\end{array}$ & $\begin{array}{c}\text { Realization } \\
2019\end{array}$ & $\begin{array}{c}\% \\
\text { Achievem } \\
\text { ents } 2019\end{array}$ & $\begin{array}{c}\% \\
\text { Achieve } \\
\text { ments } \\
2018\end{array}$ & $\begin{array}{c}\% \\
\text { Achieveme } \\
\text { nts } 2017\end{array}$ \\
\hline 1 & 2 & 3 & 4 & 5 & 6 \\
\hline $\begin{array}{l}\text { Percentage of civil } \\
\text { servants following } \\
\text { standardization } \\
\text { training }\end{array}$ & $90 \%$ & $88,48 \%$ & $98,31 \%$ & $92,57 \%$ & $103,57 \%$ \\
\hline $\begin{array}{l}\text { Percentage of ASN } \\
\text { who participated in } \\
\text { the assessment }\end{array}$ & $80 \%$ & $70,76 \%$ & $88,45 \%$ & $74,49 \%$ & $102,76 \%$ \\
\hline Average & formanc & & $93,38 \%$ & $83,53 \%$ & $103,17 \%$ \\
\hline
\end{tabular}

Based on the table above, the achievement of strategic goals for the realization of career planning and development for civil servants based on qualifications and competencies is $93.38 \%$, meaning that there is a decrease in performance when compared to 2017 which reached $103.17 \%$. Meanwhile, compared to 2018, there has been an increase in performance achievements, where in 2018 it only reached $83.53 \%$. Referring to Permendagri Number 54 of 2010 concerning the Stages, Procedures for Compiling, Controlling, and Evaluating the Implementation of the Regional Development Plan, the score of $93.38 \%$ indicates that this strategic target has received a "very good" assessment criteria.

Table 3 :

Achievement of Target Performance in 2019

Goal 3: The realization of measurable performance appraisals and work behavior in order to achieve proportional reward and punishment

\begin{tabular}{|c|c|c|c|c|c|}
\hline \multirow[t]{2}{*}{ Goal Indicator } & Target & Realization & $\%$ & $\%$ & $\%$ \\
\hline & 2019 & 2019 & $\begin{array}{c}\text { Achieve } \\
\text { ments } \\
2019\end{array}$ & $\begin{array}{c}\text { Achieve } \\
\text { ments } \\
2018\end{array}$ & $\begin{array}{c}\text { Achieve } \\
\text { ments } \\
2017\end{array}$ \\
\hline 1 & 2 & 3 & 4 & 5 & 6 \\
\hline $\begin{array}{l}\text { The scope of the } \\
\text { development of }\end{array}$ & 39 OPD & 40 OPD & $102,56 \%$ & $100 \%$ & $100 \%$ \\
\hline
\end{tabular}


Natalia Kusuma Dewi, Hardi Warsono, Ida Hayu Dwimawanti; Performance Analysis of ... $\mid 443$

\begin{tabular}{|c|c|c|c|c|c|}
\hline \multicolumn{6}{|l|}{$\begin{array}{l}\text { the State Civil } \\
\text { Apparatus }\end{array}$} \\
\hline $\begin{array}{l}\text { Disciplinary } \\
\text { violation rate }\end{array}$ & $0,5 \%$ & $22,50 \%$ & $45 \%$ & $46,66 \%$ & $30 \%$ \\
\hline & erform & & $73,78 \%$ & $73,33 \%$ & $65 \%$ \\
\hline
\end{tabular}

Based on the table above, the achievement of Strategic Targets The realization of measurable performance appraisals and work behaviors in order to achieve proportional reward and punishment of $73.78 \%$, meaning that there is an increase in performance achievements when compared to 2017 which only reached $65 \%$ and 2018 with achievements of $73,33 \%$. Referring to Permendagri Number 54 of 2010 concerning Stages, Procedures for Compiling, Controlling, and Evaluating the Implementation of the Regional Development Plan, the score of $73.78 \%$ indicates that this strategic target has received a "moderate" assessment criteria.

Table 4:

Achievement of Target Performance in 2019 Goal 4: Develop comprehensive and up-to-date ASN data for policy making

\begin{tabular}{|c|c|c|c|c|c|}
\hline Goal Indicator & $\begin{array}{c}\text { Target } \\
2019\end{array}$ & $\begin{array}{c}\text { Realization } \\
2019\end{array}$ & $\begin{array}{c}\% \\
\text { Achieve } \\
\text { ments } \\
2019\end{array}$ & $\begin{array}{c}\% \\
\text { Achieve } \\
\text { ments } \\
\mathbf{2 0 1 8}\end{array}$ & $\begin{array}{c}\% \\
\text { Achieve } \\
\text { ments } \\
2017\end{array}$ \\
\hline 1 & 2 & 3 & 4 & 5 & 6 \\
\hline $\begin{array}{l}\text { The scope of the } \\
\text { personnel } \\
\text { information system } \\
\text { development }\end{array}$ & $\begin{array}{c}2 \\
\text { Module }\end{array}$ & 2 Module & $100 \%$ & $100 \%$ & $100 \%$ \\
\hline \multicolumn{3}{|c|}{ Average Performance } & $100 \%$ & $100 \%$ & $100 \%$ \\
\hline
\end{tabular}

Based on the table above, the Strategic Target achievements of developing complete and upto-date ASN data for policy making are 100\%, meaning that from 2017 to 2019, the achievement of excellent performance is $100 \%$. Referring to Permendagri Number 54 of 2010 concerning Stages, Procedures for Compiling, Controlling, and Evaluating the Implementation of the Regional Development Plan, a score of $100 \%$ indicates that this strategic target has received a "very good" assessment criteria.Based on the calculation table of the four targets, the results of the performance achievement show that the average performance achievement of the 4 (four) targets is $90.98 \%$. This success was contributed by 1 (one) target that achieved a $100 \%$ success rate, and 3 (three) targets below 100\%, namely $96.75 \%, 93.38 \%$ and $73.78 \%$. In detail, the level of achievement of all targets is as follows: 
444 Jurnal Ilmiah Ilmu Administrasi Publik: Jurnal Pemikiran dan Penelitian Administrasi Publik

Volume 10 Number 2, July-December 2020. Page 439-445

Table 5 :

Target and Performance Achievement Value in 2019Performance Problems Civil Service Agency (BKD) Rembang Regency

\begin{tabular}{clc}
\hline No. & \multicolumn{1}{c}{ Target } & \multicolumn{1}{c}{$\begin{array}{c}\text { Value of } \\
\text { Performance } \\
\text { Achievement }\end{array}$} \\
\hline 1. & $\begin{array}{l}\text { Improved infrastructure and instruments in support of } \\
\text { staffing services and education and training }\end{array}$ & $96,75 \%$ \\
\hline 2. & $\begin{array}{l}\text { The realization of career planning and development for } \\
\text { civil servants (PNS) based on qualifications and } \\
\text { competencies }\end{array}$ & $93,38 \%$ \\
\hline 3. & $\begin{array}{l}\text { Realization of performance appraisals and measurable } \\
\text { work behavior in order to achieve proportional reward and } \\
\text { punishment }\end{array}$ & $\mathbf{7 3 , 7 8 \%}$ \\
\hline 4. & \multicolumn{1}{c}{ Teveloping complete and up-to-date ASN data for policy } \\
making & $\mathbf{1 0 0 \%}$ \\
\hline
\end{tabular}

The problems in achieving the 2019 Rembang Regency Regional Personnel Agency Target Indicator include:

1. Selection activity for senior high-ranking officials for heads of regional apparatus (echelon II / b) with a percentage of 0\% (not implemented) because the existing Echelon II positions have been filled so that no open selection is carried out.

2. Structural Position Competency Test Activities with a percentage of 0\% (not implemented) because the mutation selection committee has not yet been formed.

3. Selection for Civil Servant Candidates reached a percentage of $35.38 \%$ because spending on short courses / training used to contribute to determining the NIP was not taken because they did not pay and there was no rental vehicle / official trips outside the region.

4. Administrative Activities of Decree on Appointment of CPNS to PNS with a percentage of $0 \%$ (not implemented) because the CPNS formation in 2018 were only appointed as PNS in 2020.

5. The activity of organizing the ceremony for taking the pledge of civil servants has achieved 0\% performance (not implemented) because in 2019 there were no civil servants who had not taken the oath of promise.

6. The PNS Health Check activity reaches a percentage of $37.49 \%$ because in Rembang Regency already has a team of health examiners so that official trips outside the region are not used

7. The SKP Implementation Evaluation Activity reached a percentage of $46.29 \%$ because in 2019 BKN has used the E-Lapkin application so that it does not need an official travel 
budget to send files and SKP problems throughout 2019 are not too large so they do not require coordination with the state civil service agency

\section{CONCLUSION}

The achievement of an organization is inseparable from the ability of the organization's resources so that what the goals or objectives can be achieved, in other words, whether the vision, mission or plans with targets can be evaluated as a basis for measuring the level of effectiveness If what the organization plans can be achieved, it can be said to be effective, but on the other hand, what the organization has planned has not been achieved, then it is not effective and becomes material for future evaluation.

The results of the performance achievement show that the average performance achievement of the 4 (four) targets is $90.98 \%$. The performance achievement of each target includes; 1 ). Increased infrastructure and instruments in support of personnel services and education and training by $96.75 \%$; 2). The realization of qualification and competency-based civil servant career planning and development of $93.38 \% .3$ ). The realization of performance appraisals and measurable work behavior in order to achieve proportional reward and punishment of 73.78\%. 4). Developed complete and up-to-date ASN data for $100 \%$ policy making.

Recommendations that need to be made to overcome the problems faced include:

1. Coordinate with the Central Government regarding activities to be implemented so that they can meet the targets for implementing these activities.

2. More maturity of budget preparation in coordination with related fields.

\section{REFERENCES}

Anwar Prabu Mangkunegara, 2014, Manajemen Sumber Daya Manusia Perusahaan, Bandung: PT. Remaja Rosdakarya Offset.

Daft, Richard L. 2006. Manajemen. Jakarta : Salemba Empat

Handoko, T. Hani.2008. Manajemen. Edisi 2. Yogyakarta: BPFE

Hasibuan, M, S.P. 2002. Manajemen Dasar, Pengertian dan Masalah. PT Toko Gunung Agung. Jakarta.

Hendry Simamora. 2014. Manajemen Sumber Daya Manusia, Cetakan Pertama, Penerbit BP - STIE YKPN, Yogyakarta.

J Winardi. 2007. Manajemen Perilaku Organisasi. Jakarta : Kencana

Miles, M.B, Huberman, A.M, dan Saldana, J. (2014). Qualitative Data Analysis, A Methods Sourcebook Edition 3. USA: Sage Publications.

Moeloeng, Lexy J. (2012). Metodologi Penelitian Kualitatif. Bandung: PT. Remaja Rosda Karya Sugiyono. (2015). Metode Penelitian Kuantitatif Kualitatif dan R\&D. Bandung: Alfabeta 